\title{
Applicability of the Philosophy and Mission-Vision of The Schools of Select Teachers to their Learning Plans
}

\author{
Mark Lester C. Cuayzon \\ mark.cuayzon@deped.gov.ph \\ Department of Education-Manila-Manuel A. Roxas High School, Paco, Manila, Philippines
}

\begin{abstract}
This study focused on the applicability of the philosophy, mission, and vision statements on their learning plans of the different schools of select MA students enrolled in The National Teachers College. The study only included the randomly picked 20 teachers as respondents. They were teaching in both public and private schools around Metro Manila. This study aimed to give the schools information as to what extent the teachers apply their respective philosophy, mission, vision and how the teachers integrate them in their daily learning plans. It also gave them insights about the common problems that teachers encountered in the integration of these statements in the learning plans. The study revealed that the teachers almost always applied or integrated their school's philosophy, mission-vision to their learning objectives, to their lesson proper or activities, and to evaluation part of their learning plans. The study also had shown that the teachers considered the schools' philosophy, mission-vision as highly influential in their choice of activities as it is reflected in the grand average in terms of the availability of the resources, students' diversity, time consumption, nature/ content of the activity and difficulty of the subject matter. The teachers regarded the problems such as insufficient instructional time, practicality of the schools' philosophy, mission-vision, and the irrelevance of the school's curriculum in the integration of these statements to their learning plans as quite serious.
\end{abstract}

Keywords: Education; Mission-Vision; Philosophy; School

\section{Introduction}

Philosophy and education are sometimes considered to be two sides of the same coin, with education being the dynamic side of philosophy. To elaborate, philosophy and education are two blossoms on one stalk, two sides of the same coin. One cannot exist without the other. Without the other, one is incomplete. Philosophy cannot complete the art of education, and education cannot convert others to its goals and principles. Philosophy is the study of truths and the quest of understanding. Philosophy is a way of living. Philosophy, in a broader sense, is a way of thinking about life, nature, and truth. It establishes the benchmarks for an individual to reach throughout his lifetime. On the other hand, education is the more active aspect of philosophy. It is the active component and means of putting life's values into practice.

In the field of education, philosophy is applied to have a wider and overseeing perspective of the future of an institution. It also important to plan such philosophy, mission-vision statements in order to be productive and efficient in every activity to be made. Emerging strong philosophy, vision, and mission statements can assist school shareholders in achieving such a common purpose. The school's vision is where it wants to go in the future. The mission provides a summary of the phases that will follow in the future. A vision is short and easy to remember, whereas a mission is longer and more detailed. Along the way, the school may choose to set goals to track progress toward its vision. The researchers strive to figure out how the 
school's philosophy, vision, and mission statement will influence instructors' ability to be more effective in respective fields.

These three - philosophy, mission, vision are essential components to serve the purpose of the school. They are all directly related and part of each other but are also individual components that have unique meaning and role in the bigger scale of a program. It motivates grade-level teams, curricular teams, and departments to make significant progress. It comprises precise strategies that lead reform efforts throughout the year and includes detailed expectations for administrators, teachers, counsellors, and other stakeholders. Realizing the school's philosophy, mission and vision should reflect on the teachers' preparation much more on his/her learning plans and upon giving varied activities. High-stakes assessments, advanced examinations, and other assessment methods will be used to increase student achievement.

\section{Conceptual Framework}

In a more comprehensive manner, the researchers have made a structure to direct them into the proper operation of the approaches and strategies in dealing with the research as it goes deep. Interest in this topic has increased recently, particularly with regard to institutional system coordination and anchoring with systems' philosophy, mission, and vision. Schools can develop their vision and mission statements, which act as the school's road map for the years ahead. School improvement elements include such statements as components of success (Gitomer, 2009). Drafting statements is not enough. Schools should model the institution's beliefs, values, and collective commitments while demonstrating excitement about what lies ahead.

Setting expectations and standards are an essential part of defining a vision and mission. The integration and proper application of the school's philosophy and mission-vision will achieve the alignment of the two. Teachers are also able to assess the lessons Ramsey (2010). Philosophy influences education in various ways. while philosophical viewpoints inform us that each of these questions falls on one of the two poles in a spectrum of philosophical positions (Pui-wah, 2008). considering the nature of the earner, the subject matter, and how should subject matter guide students' learning activities (Brubacher, 1962).

Today, education is plagued by incessant calls for immediate and practical solutions. Once you demand that it be applied "practically," it loses its spark. Philosophy is a cerebral and leisurely activity; it must be taken in its entirety for its own sake. Because education is concerned with issues of choice, action, and judgment, understanding the issues of the practical realm is important. The student-teacher educator philosophy is therefore an essential educational discipline (DSOUZA, 1992).

\section{Statement of the Problem}

This study wassought to answer the following specific questions:

1. How often does the integration of the school's philosophy, mission-vision is utilized to the following parts of the learning plan:

1.1. Learning objectives,

1.2. Lesson proper; and

1.3. Evaluation?

2. How does the philosophy, mission-vision influence the teachers' choice of activities?

3. What are the teachers' problems in integrating the schools' philosophy, mission-vision to their learning plans?

4. What are the actions/measures to address the problems/ concerns?

\section{Review of Related Literature and Studies}

The researcher carefully reviewed similar pertinent materials and studies related to impact of the school's philosophy, mission-vision to the teachers' daily learning plans and schools' activities on academics. 


\section{Philosophy and Its Implication to Education}

Schools formulate their philosophies, missions, and visions in order to set direction for their educational process. education imparts ideals, values, and principles that all schools hope to impart Despite poor logical rigor, usefulness and communicative power are very high. Also, the "educational implication" is usually seen as moving from philosophy to education. The presuppositions of an educational action are stated as premises in implications that yield educational conclusions (Conklin, 2007).

The school development planning is most effective when it is closely linked to a clearly written, collaboratively created statement of school values and beliefs (Miller, 2013). The schools which remain complacent, which continue to hang on to traditional beliefs are among the very best and thus, fail to anticipate the future will find themselves lagging or worse ceasing to exist (Abasolo, 1991). The emerging trends in the field of education cannot be ignored since these necessitates changes that reshape schools and dictate core values, vision-mission and goals and strategies to bring the school us to where administrators want to go (The Executive Edge).

\section{Philosophy in Teaching}

To modify a child's innate behavior, you must modify it in a particular direction and impart certain values. Philosophy shows the educator the way to modify the child's behavior (Ghosh, 2011). Thus, philosophy is about end results, and education is a proving ground for philosophical theories and speculations. He also said that education is the best means for the propagation of philosophy.

Teachers' approach to education is a window to the world and a compass in life. It is shown in the way he interacts with students, colleagues, parents, and administrators. That leads to the teachers' attitudes and behavior in the educational process (Bilbao \& Salandanan, 2006).

Teacher is one of the fundamental aspects of the educational process. The teacher is a mentor, director, and educational leader in the educational process. A successful teacher is the one who can organize the work and classroom life. The teacher's philosophy affects the learners both emotional aspects and behaviors. Having a sound teaching philosophy can provide a great classroom ambiance, which aid gaining good learning outcomes.

\section{Methodology}

Quantitative method of research was used by the researchers in conducting the study entitled "Applicability of the Philosophy, Mission-Vision of the Schools of Select Teachers to their Learning Plans". Quantitative research is to conduct systematic empirical investigation of quantitative properties in order to yield accurate assessment of incidence. In addition, this establishes the connection between empirical observation and mathematical expression of quantitative relationships.

\section{Instruments and Techniques}

To obtain the much-needed data in determining the applicability of the philosophy, mission-vision of schools of MA students enrolled at The National Teachers College on their learning plans, the researchers used questionnaires as the primary tools in gathering data from the teachers in public and private schools.

\section{Questionnaire}

Data were gathered from the teachers through questionnaires. The questionnaires from the teachers provide information on the applicability of the philosophy, mission-vision statements on their learning plans.

\section{Preparation}

Prior to the construction of the survey questionnaires, the researchers referred and read the related books and studies to guide them as to what the direction they are heading in the course of the study. The 
survey questionnaires were double checked by the experts to check the content of the questions.

\section{Sampling Procedure}

This study included 20 MA students from The National Teachers College. Simpler random sampling was used, since it only involved a few MA students enrolled during the summer. A simple random sample has every member of the population having an equal chance of being chosen to form the sample. It was most convenient for the researchers in consideration to the time frame given.

\section{Treatment of Data}

Responses were tallied, tabulated, subjected to statistical treatment, and then interpreted.

Weighted Average. The weighted average was used in all of the questions in the questionnaire to compute the data. The formula used on computing the weighted average is $W A=\frac{T W}{N}$

Where: $T W$ is Total Weight $N=$ Number of Respondents

The weighted average is given the following verbal description.

\begin{tabular}{ccl}
\hline Average Weight & Weighted Average & \multicolumn{1}{c}{ Description } \\
\hline 5 & $4.50-5.00$ & Always/Highly Influential/Highly Serious \\
4 & $3.50-4.49$ & Almost Always/ Very Influential/ Very Serious \\
3 & $2.50-3.49$ & Frequently/ Moderately Influential/ Moderately Serious \\
2 & $1.50-2.49$ & Seldom/ Slightly Influential/ Slightly Serious \\
1 & $1.00-1.49$ & Never/ Not Influential/ Not Serious
\end{tabular}

\section{Discussions}

The arrangement of data was also in accordance to the organization of the problems. Primarily, data were derived from the retrieved responses from the questionnaire and interview. Data were analyzed and tabulated for better perception and sequence of answering the problem. In order to gather the data, simple random sampling was used to determine the 20 respondents.

\section{Frequency of the Integration of School's Philosophy to the parts of the Lesson Plan}

The researchers conducted a survey on the frequency of the integration of school's philosophy to the parts of the lesson plan (learning objectives, lesson proper, evaluation) and got the general weighted average from the respondents' responses. These are shown in Tables 1-3.

\section{In the Learning Objectives}

The researchers got the weighted average of the data of the frequency of the integration of the school's philosophy to the learning objectives.

Table 1 shows the frequency of the integration of school's philosophy to the learning objectives. It shows that the answer "I align my learning objectives to the philosophy of the school" ranked first and got a total weight of 81 and weighted average of 4.05 with a verbal description of almost always. The answer "I make outright decisions upon crafting my learning objectives" ranked second and got a total weight of 79 and weighted average of 3.95 with a verbal description of almost always. The last is the answer "I consider the school's philosophy before I formulate my learning objectives" and got a total weight of 78 and weighted average of 3.90 with a verbal description of almost always. 
Table 1

Frequency of the Integration of School's Philosophy to the Learning Objectives

\begin{tabular}{clcccc}
\hline 1.1. Learn & $\begin{array}{c}\text { TOTAL } \\
\text { WEIGHT }\end{array}$ & $\begin{array}{c}\text { WEIGHTED } \\
\text { AVERAGE }\end{array}$ & $\begin{array}{c}\text { VERBAL } \\
\text { DESCRIPTION }\end{array}$ & RANK \\
\hline 1.1.1. & $\begin{array}{l}\text { I align my learning } \\
\text { objectives to the } \\
\text { philosophy of the } \\
\text { school. }\end{array}$ & 81 & 4.05 & Almost Always & 1 \\
1.1.2. $\quad \begin{array}{l}\text { I consider the school's } \\
\text { philosophy before I } \\
\text { formulate my learning } \\
\text { objectives. }\end{array}$ & 78 & 3.90 & Almost Always & 3 \\
$\begin{array}{l}\text { I make outright } \\
\text { decisions upon crafting } \\
\text { my learning objectives. }\end{array}$ & 79 & 3.95 & Almost Always & 2 \\
Grand Average & & 3.96 & Almost Always
\end{tabular}

It shows that respondents almost always aligned their learning objectives to the school's philosophy and it is the first consideration in formulating such objectives. Also, the respondents make outright and spontaneous decisions depending on the needs of the students however, they make sure that it is somehow aligned with the schools' philosophy. Although it has a verbal description of almost always, the respondents least considered the school's philosophy before formulating the learning objectives because many changes will happen upon the attainment of such objectives depending on the needs, interests and capabilities of each student.

\section{In the Lesson Proper}

The researchers got the weighted average of the data of the frequency of the integration of the school's philosophy to the learning objectives. It is shown in table 2.

Table 2

Frequency of the Integration of School's Philosophy to the Lesson Proper

\begin{tabular}{cl}
\hline 1.2. & Lesson Proper/ Activities \\
\hline 1.2.1. & I see to it that the activities \\
& (e.g. seatworks, drills, \\
& exercises) are aligned to the \\
& school's philosophy
\end{tabular}

1.2.2. I consider first the school's TOTAL WEIGHTED VERBAL WEIGHT AVERAGE DESCRIPTION

RANK

79
3.95

Almost Always 1 philosophy before giving varied activities.

1.2.3. I give spontaneous tasks as needed even if it is not in the 
lesson plan.

\section{Grand Average $\quad 3.75 \quad$ Almost Always}

Table 2 shows the frequency of the integration of school's philosophy to the lesson proper. It shows that the answer "I see to it that the activities (e.g. seat works, drills, exercises) are aligned to the school's philosophy" ranked first and got a total weight of 79 and weighted average of 3.95 with a verbal description of almost always. The answer "I consider first the school's philosophy before giving varied activities" ranked second and got a total weight of 75 and weighted average of 3.75 with a verbal description of almost always. The last is the answer "I give spontaneous tasks as needed even if it is not in the lesson plan" and got a total weight of 71 and weighted average of 3.55 with a verbal description of almost always.

It shows that respondents almost always aligned their activities to the school's philosophy. The alignment of the activities to the schools' philosophy is important because it will guide the respondents to what extent they will give such activity. The respondents see to it that they do not go away with the philosophy of the school upon giving varied activities. Conversely, the respondents consider their activities to be unified with the school's philosophy because they want to see the consistency in their activities. Although it has a verbal description of almost always, give spontaneous tasks even if it is not in the lesson plan as the need arises.

\section{In the Evaluation}

The researcher got the weighted average of the data of the frequency of the integration of the school's philosophy to the evaluation.

Table 3

Frequency of the Integration of School's Philosophy to the Evaluation

\begin{tabular}{|c|c|c|c|c|c|}
\hline \multicolumn{2}{|c|}{ 1.3. Evaluation } & \multirow{2}{*}{$\begin{array}{c}\text { TOTAL } \\
\text { WEIGHT } \\
77\end{array}$} & \multirow{2}{*}{$\begin{array}{c}\text { WEIGHTED } \\
\text { AVERAGE } \\
3.85\end{array}$} & \multirow{2}{*}{$\begin{array}{c}\text { VERBAL } \\
\text { DESCRIPTION } \\
\text { Almost Always }\end{array}$} & \multirow{2}{*}{$\begin{array}{c}\text { RANK } \\
2\end{array}$} \\
\hline 1.3.1. & $\begin{array}{l}\text { I evaluate my students } \\
\text { based on the philosophy } \\
\text { of the school. }\end{array}$ & & & & \\
\hline 1.3.2. & $\begin{array}{l}\text { I evaluate to see if my } \\
\text { students are capable of } \\
\text { passing the subject. }\end{array}$ & 85 & 4.25 & Almost Always & 1 \\
\hline \multirow[t]{2}{*}{ 1.3.3. } & $\begin{array}{l}\text { I evaluate my students } \\
\text { based on my own } \\
\text { standards }\end{array}$ & 71 & 3.55 & Almost Always & 3 \\
\hline & Grand Average & & 3.88 & Almost Always & \\
\hline \multicolumn{6}{|c|}{$\begin{array}{l}\text { Table } 3 \text { shows the frequency of the integration of school's philosophy to the evaluation part of the } \\
\text { lesson plan or learning plans. It shows that the answer "I evaluate to see if my students are capable of passing } \\
\text { the subject" ranked first and got a total weight of } 85 \text { and weighted average of } 4.25 \text { with a verbal description of } \\
\text { almost always. The answer "I evaluate my students based on the philosophy of the school" ranked second and } \\
\text { got a total weight of } 77 \text { and weighted average of } 3.85 \text { with a verbal description of almost always. The last is } \\
\text { the answer "I evaluate my students based on my own standards" and got a total weight of } 71 \text { and weighted } \\
\text { average of } 3.55 \text { with a verbal description of almost always. } \\
\text { Based on the data, it shows that the respondents evaluate the students to see if they can pass the subject. } \\
\text { It means that their primary goal is to assess the students' performance to be able to pass the subject. However, }\end{array}$} \\
\hline
\end{tabular}


they at least considered the school's philosophy which reflected on the ranked two of the table. There are some respondents who based their evaluation on the schools' philosophy because they based on it primarily on the standards of the school and some who based on their own standards or criteria.

\section{Frequency of the Integration of School's Mission to the parts of the Lesson Plan}

The frequency of the integration of school's mission to the parts of the lesson plan (learning objectives, lesson proper, evaluation) are shown in Tables 4-6.

\section{In the Learning Objectives}

The researcher got the weighted average of the data of the frequency of the integration of the school's mission to the learning objectives. It is shown in table 4.

Table 4

Frequency of the Integration of School's Mission to the Learning Objectives

\begin{tabular}{clcccr}
\hline 2.1. & Learning Objectives & $\begin{array}{c}\text { TOTAL } \\
\text { WEIGHT }\end{array}$ & $\begin{array}{c}\text { WEIGHTED } \\
\text { AVERAGE }\end{array}$ & $\begin{array}{c}\text { VERBAL } \\
\text { DESCRIPTION }\end{array}$ & RANK \\
\hline 2.1.1. & $\begin{array}{l}\text { I align my learning } \\
\text { objectives to the } \\
\text { mission of the school }\end{array}$ & 82 & 4.10 & Almost Always & 2 \\
2.1.2. & $\begin{array}{l}\text { I make sure that my } \\
\text { learning objectives are } \\
\text { attainable as what is } \\
\text { stated to the school's } \\
\text { mission }\end{array}$ & 85 & 4.25 & Almost Always & 1 \\
2.1.3. & $\begin{array}{l}\text { I make idealistic } \\
\text { objectives so that my } \\
\text { students achieve } \\
\text { academic excellence. }\end{array}$ & 73 & 3.65 & Almost Always & 3 \\
& & & & \\
\end{tabular}

Grand Average

4.00 Almost Always

Table 4 shows the frequency of the integration of school's mission to the learning objectives. It shows that the answer "I make sure that my learning objectives are attainable as what is stated to the school's mission" ranked first and got a total weight of 85 and weighted average of 4.25 with a verbal description of almost always. The answer "I align my learning objectives to the mission of the school" ranked second and got a total weight of 82 and weighted average of 4.10 with a verbal description of almost always. The last is the answer "I make idealistic objectives so that my students achieve academic excellence" and got a total weight of 73 and weighted average of 3.65 with a verbal description of almost always.

It shows that the respondents assured first that their learning objectives are attainable as what is stated on the school's mission. They also wanted doable objectives which can be attain on a specific time to avoid cramming and congestion of information. There are some respondents who aligned first their objectives to the mission statement to see if it is parallel to each other and follows the mission statement of their school. However, there are some respondents who make ideal objectives to achieve academic excellence because it will set standards to exhaust the maximum potentials of the students. 


\section{In the Lesson Proper}

The researcher got the weighted average of the data of the frequency of the integration of the school's philosophy to the lesson proper.

Table 5

Frequency of the Integration of School's Mission to the Lesson Proper

\begin{tabular}{|c|c|c|c|c|c|}
\hline \multicolumn{2}{|c|}{ 2.2. Lesson Proper/ Activities } & $\begin{array}{c}\text { TOTAL } \\
\text { WEIGHT }\end{array}$ & $\begin{array}{l}\text { WEIGHTED } \\
\text { AVERAGE }\end{array}$ & $\begin{array}{c}\text { VERBAL } \\
\text { DESCRIPTION }\end{array}$ & RANK \\
\hline 2.2.1. & $\begin{array}{l}\text { I see to it that the } \\
\text { activities (e.g. } \\
\text { seatworks, drills, } \\
\text { exercises) are realistic } \\
\text { and possible to } \\
\text { achieve the school's } \\
\text { mission. }\end{array}$ & 79 & 3.95 & Almost Always & 3 \\
\hline 2.2.2. & $\begin{array}{l}\text { I make sure that I } \\
\text { always give varied } \\
\text { activities that are } \\
\text { mandated to the } \\
\text { school's mission. }\end{array}$ & 81 & 4.05 & Almost Always & 1.5 \\
\hline 2.2.3. & $\begin{array}{l}\text { If necessary, I give } \\
\text { tasks based on the } \\
\text { needs of the learners } \\
\text { even if it is not in the } \\
\text { mission statement of } \\
\text { the school. }\end{array}$ & 81 & 4.05 & Almost Always & 1.5 \\
\hline & Grand Average & & 4.01 & Almost Always & \\
\hline
\end{tabular}

Table 5 shows the frequency of the integration of school's mission to the lesson proper. It shows that the answers "I make sure that I always give varied activities that are mandated to the school's mission" and "If necessary, I give tasks based on the needs of the learners even if it is not in the mission statement of the school" both ranked $1.5^{\text {th }}$ and got a total weight of 81 and weighted average of 4.05 with a verbal description of almost always. The last is the answer "I see to it that the activities (e.g. seatworks, drills, exercises) are realistic and possible to achieve the school's mission" and got a total weight of 79 and weighted average of 3.95 with a verbal description of almost always.

It shows that respondents give different activities which are mandated to their school's mission at the same time they give necessary tasks depending to the needs of the students because all of the activities are primarily based on the needs and interests of the learners and which is anchored to the school's mission. In contrast, other respondents considered the realistic and likely prospect of the activities as they all have both practicality and convenience for both the respondents and the students.

\section{In the Evaluation}

The researchers got the weighted average of the data of the frequency of the integration of the school's mission to the learning objectives. It is shown in table 6 
Table 6

Frequency of the Integration of School's Mission to the Evaluation

\begin{tabular}{|c|c|c|c|c|c|}
\hline \multicolumn{2}{|c|}{ 2.3. Evaluation } & \multirow{2}{*}{$\begin{array}{c}\text { TOTAL } \\
\text { WEIGHT } \\
76\end{array}$} & \multirow{2}{*}{$\begin{array}{c}\text { WEIGHTED } \\
\text { AVERAGE } \\
3.80\end{array}$} & \multirow{2}{*}{$\begin{array}{c}\text { VERBAL } \\
\text { DESCRIPTION } \\
\text { Almost } \\
\text { Always }\end{array}$} & \multirow{2}{*}{$\begin{array}{c}\text { RANK } \\
2\end{array}$} \\
\hline 2.3.1. & $\begin{array}{l}\text { I evaluate my students } \\
\text { based on the mission } \\
\text { of the school. }\end{array}$ & & & & \\
\hline 2.3.2. & $\begin{array}{l}\text { I use the mission } \\
\text { statement of the school } \\
\text { as a standard on giving } \\
\text { remark to the students. }\end{array}$ & 74 & 3.70 & $\begin{array}{l}\text { Almost } \\
\text { Always }\end{array}$ & 3 \\
\hline 2.3.3. & $\begin{array}{l}\text { I evaluate my students } \\
\text { based on what they } \\
\text { deserve. }\end{array}$ & 86 & 4.30 & $\begin{array}{l}\text { Almost } \\
\text { Always }\end{array}$ & 1 \\
\hline & Grand Average & & 3.93 & Almost Always & \\
\hline
\end{tabular}

Table 6 shows the frequency of the integration of school's mission to the evaluation part of the lesson plan or learning plan. It shows that the answer "I evaluate my students based on what they deserve" ranked first and got a total weight of 86 and weighted average of 4.30 with a verbal description of almost always. The answer "I evaluate my students based on the mission of the school" ranked second and got a total weight of 76 and weighted average of 3.80 with a verbal description of almost always. The last is the answer "I use the mission statement of the school as a standard on giving remark to the students" and got a total weight of 74 and weighted average of 3.70 with a verbal description of almost always.

It shows that most of the respondents evaluate the students based on what they deserve. It means that the respondents are evaluating the direct performances of the students and give remarks based on the standards set by the respondents. However, there are some respondents who use the mission statement as a basis on giving evaluation because they believed that it can give what is being asked by the school. Finally, some respondents directly use the mission statement as a standard on giving remarks because it empowers them and promotes their association with the school.

\section{Frequency of the Integration of School's Vision to the parts of the Lesson Plan}

The frequency of the integration of school's vision to the parts of the lesson plan (learning objectives, lesson proper, evaluation) are shown in Tables 7-9.

\section{In the Learning Objectives}

The researchers got the weighted average of the data of the frequency of the integration of the school's vision to the learning objectives. It is shown in table 7.

Table 7

Frequency of the Integration of School's Vision to the Learning Objectives

\begin{tabular}{llcccc}
\hline 3.1. Learning Objectives & $\begin{array}{c}\text { TOTAL } \\
\text { WEIGHT }\end{array}$ & $\begin{array}{c}\text { WEIGHTED } \\
\text { AVERAGE }\end{array}$ & $\begin{array}{c}\text { VERBAL } \\
\text { DESCRIPTION }\end{array}$ & RANK \\
\hline 3.1.1. & $\begin{array}{l}\text { My learning } \\
\text { objectives are } \\
\text { congruent with }\end{array}$ & 79 & 3.95 & Almost & 2.5 \\
Always & & & \\
\end{tabular}


the school's

vision.
3.1.2. I make sure that
my learning
objectives are
achievable based
on the vision
statement of the
school. 83

Almost Always

1

3.1.3. I make

Almost Always

2.5

principled

objectives which

are directly

congruent to the

school's vision.

\section{Grand Average}

4.01

Almost Always

Table 7 shows the frequency of the integration of school's vision to the learning objectives. It shows that the answer "I make sure that my learning objectives are achievable based on the vision statement of the school" ranked first and got a total weight of 83 and weighted average of 4.15 with a verbal description of "Almost Always". The answer "My learning objectives are congruent with the school's vision" and "I make principled objectives which are directly congruent to the school's vision." both ranked second and got a total weight of 79 and weighted average of 3.95 with a verbal description of "Almost Always".

The table demonstrates that the respondents make sure that the learning objectives are achievable based on the vision statement of the school. This is to increase the teachers' accountability for the learning of the students. Moreover, having achievable objectives provides teachers and students a concrete picture of what supposed to be attained at the end of the lesson.

\section{In the Lesson Proper}

The researchers got the weighted average of the data of the frequency of the integration of the school's vision to the lesson proper.

The frequency of the integration of school's vision to the lesson proper is revealed in table 8 . The item "If necessary, I give tasks based on the needs of the learners just to attain the vision of the school." got the total weight of 79 and a weighted average of 3.95 with a verbal description of almost always, which ranked first. The items " I see to it that the activities (e.g. seat works, drills, exercises) are realistic and possible to achieve the school's vision." and " I see to it that the activities (e.g. seat works, drills, exercises) are realistic and possible to achieve the school's vision.", shared the same rank. They received a total weight of 77 and a weighted average of 3.85 and still have a verbal description of almost always.

Table 8

Frequency of the Integration of School's Vision to the Lesson Proper

\begin{tabular}{llcccc}
\hline 3.2. & $\begin{array}{l}\text { Lesson Proper/ } \\
\text { Activities }\end{array}$ & $\begin{array}{c}\text { TOTAL } \\
\text { WEIGHT }\end{array}$ & $\begin{array}{c}\text { WEIGHTED } \\
\text { AVERAGE }\end{array}$ & $\begin{array}{c}\text { VERBAL } \\
\text { DESCRIPTION }\end{array}$ & RANK \\
\hline $\mathbf{3 . 2 . 1 .}$ & $\begin{array}{l}\text { I see to it that the } \\
\text { activities (e.g. }\end{array}$ & 77 & 3.85 & $\begin{array}{c}\text { Almost } \\
\text { Always }\end{array}$ & 2.5 \\
\end{tabular}


seatworks, drills,

exercises) are

realistic and

possible to achieve

the school's

vision.

3.2.2. I make sure that every activity that I give is a key to attain the school's vision.

3.2.3. If necessary, I give tasks based on the needs of the learners just to attain the vision of the school.

\section{Grand Average}

It shows that the respondents give activities that can be used as means of realizing the schools' vision statements. The respondents also choose activities that are linked to reality and are crucial to the development of the students. Activities are ought to show the relevance of the lesson to the students' lives and experiences for learning to be meaningful, according to the informal interview of one of the respondents.

\section{In the Evaluation}

The researchers got the weighted average of the data of the frequency of the integration of the school's vision to the evaluation. It is shown in table 9.

Table 9

Frequency of the Integration of School's Vision to the Evaluation

\begin{tabular}{llcccc}
\hline 3.3. & Evaluation & $\begin{array}{c}\text { TOTAL } \\
\text { WEIGHT }\end{array}$ & $\begin{array}{c}\text { WEIGHTED } \\
\text { AVERAGE }\end{array}$ & $\begin{array}{c}\text { VERBAL } \\
\text { DESCRIPTION }\end{array}$ & RANK \\
\hline 3.3.1. & $\begin{array}{l}\text { I evaluate my } \\
\text { students based on } \\
\text { the vision of the } \\
\text { school. }\end{array}$ & 76 & 3.80 & Almost Always & 3 \\
& & & & \\
3.3.2. & $\begin{array}{l}\text { I use the vision } \\
\text { statement of the } \\
\text { school as a } \\
\text { standard for } \\
\text { viewing my } \\
\text { students from } \\
\text { their academic } \\
\text { performance/stat }\end{array}$ & 80 & 4.00 & Almost Always & 2 \\
& & & & \\
\end{tabular}


us.

3.3.3. I evaluate my students based on what they deserve. 87

(1)

4.35

4.05
Almost Always

1
Grand Average

\subsection{5}

\author{
Almost Always
}

In table 9, the frequency of school's vision to the evaluation is shown. The item which got the first rank is "I evaluate my students based on what they deserve." It received a total weight of 87 and a weighted average of 4.35 and a verbal description of almost always. The item "I evaluate my students based on the vision of the school." ranked last, which got a total weight of 76 and a weighted average of 3.80 with a verbal description of almost always.

Most of the respondents agreed that students should be evaluated based on what they deserve as reflected on the table. Students should be evaluated according to their nature or diversity, only then we can understand how they learn best. This is to avoid any bias judgment and students will be given what grade is duly right to them.

The Degree of the Influence of the Philosophy, Mission, Vision to the Teachers' Choice of Activities.

The degree of the influence of the philosophy, mission, vision to the teachers' choice of activities is shown in table 10

As it shown in the table, the "Availability of the resources" ranked number 1, which got the total weight of 84 and weighted average of 4.20 with a verbal description of highly influential. "Nature or the content of the activity" ranked second, which got a total weight of 82 and weighted average of 4.10 with a verbal description of highly influential. The next is "Difficulty of the subject matter" with a weighted average of 4.05 and a total weight of 81 and still got the verbal description of highly individual is the item ". The last are the items "Students Diversity" and "Time Consumption" with both has a total weight of 78 and a weighted average of 3.90

\section{Table 10}

Degree of the Influence of the Philosophy, Mission, Vision to the Teachers' Choice of Activities

\begin{tabular}{|c|c|c|c|c|c|}
\hline & & $\begin{array}{c}\text { TOTAL } \\
\text { WEIGHT }\end{array}$ & $\begin{array}{l}\text { WEIGHTED } \\
\text { AVERAGE }\end{array}$ & $\begin{array}{c}\text { VERBAL } \\
\text { DESCRIPTION }\end{array}$ & RANK \\
\hline 4.1. & $\begin{array}{l}\text { Availability of the } \\
\text { resources }\end{array}$ & 84 & 4.20 & Highly Influential & 1 \\
\hline 4.2 . & Students diversity & 78 & 3.90 & Highly Influential & 4.5 \\
\hline 4.3. & Time consumption & 78 & 3.90 & Highly Influential & 4.5 \\
\hline 4.4. & $\begin{array}{l}\text { Nature/content of the } \\
\text { activity }\end{array}$ & 82 & 4.10 & Highly Influential & 2 \\
\hline 4.5. & $\begin{array}{l}\text { Difficulty of the subject } \\
\text { matter }\end{array}$ & 81 & 4.05 & Highly Influential & 3 \\
\hline
\end{tabular}


Grand Average

4.02

\section{Highly \\ Influential}

It appears that most of the respondents consider the availability of the resources as the most influential as it reflected by its weighted average. The respondents consider the practicality of the visual aids/ materials for convenient utilization of them. Hence, the nature or content of the activity is considered secondly by the respondents for the kind of activity that the teachers will be using depends on it. In addition, the difficulty of the subject matter is considered least because the teachers still manage to discuss the subject matter regardless of its difficulty. This is to make sure that no matter how difficulty the content of the lesson, children are still acquired the desired skills.

The Degree of the Seriousness of the Teachers' Problems in Integrating the School's Philosophy, Mission, and Vision to their Learning Plans

The degree of the seriousness of the teachers' problems in integrating the school's philosophy, mission, and vision to their learning plans is shown in table 11 .

Table 11 shows the degree of seriousness of the teachers' problems in integrating the school's philosophy, mission and vision to their learning plans. The item "Some of the topics under the schools" curriculum are not relevant to the schools' philosophy, mission, vision." ranked first, which got the total weight of 77 and weighted average of 3.85 with a verbal description of quite serious. Ranked second is the item "I make sure that I integrate the school's philosophy, mission, and vision in the lesson every day that is why I often consume too much time.", which got the total average of 66 and weighted average of 3.30, with a verbal description of quite serious.

Table 11

Degree of the Seriousness of the Teachers' Problems in Integrating the School's Philosophy, Mission, and Vision to their Learning Plans

$\begin{array}{cccc}\text { TOTAL } & \text { WEIGHTED } & \text { VERBAL } & \text { RANK } \\ \text { WEIGHT } & \text { AVERAGE } & \text { DESCRIPTION } & \end{array}$

5.1. My time is only 65 3.25 Quite Serious 3 sufficient for the content of my lesson; thus, I lack time for the integration of the school's philosophy, mission, vision.

5.2. I make sure that $I$ 66 3.30

Quite Serious 2 integrate the school's philosophy, mission, and vision in the lesson every day that is why I often consume too much time.

5.3. Our school's 57 2.85 Quite Serious

philosophy, mission, vision is too ideal thus I 
don't integrate them at

all.

5.4. Some of the topics

Quite Serious

1

under the school's

curriculum are not

relevant to the school's

philosophy, mission,

vision.

Grand Average

Quite Serious

Based on the responses of the respondents, some of the topics under the school's curriculum are not relevant to the school's philosophy, mission, vision considered as the most serious problem that teachers encounter in the integration of the school's philosophy, mission and vision on the lesson plan. This is because some topics focused on facts and not on the skills or application thus do not maximize the possible purpose of these statements in relevance to the designed curriculum. Another serious problem that teachers encounter in integrating the philosophy, mission, vision of the school is the too much consumption of time to make sure the integration of these statements to the lesson. Making sure that the content of the learning plans mirrors what the schools believe in and aim for, teachers are oblige to pattern the learning plans to these statements. As a result, the teachers have the tendency to use too much time to accomplish all the tasks in the given period allotted for each subject, which may not be sufficient to cover them all.

\section{The Frequency of the Actions/ Measures to Address the Problems or Concerns}

The frequency of the actions/ measures to address the problems or concerns is shown in table 12.

To know the frequency and the common actions/measures that schools are currently exercising in addressing the above-mentioned problems in integrating the philosophy, mission, vision, the researchers also provided possible solutions that schools are already practicing. The result is shown in table 12. It shows that the item "Our school is conducting regular meetings (e.g. PLC, Departmental Meeting, Faculty Meeting) to deal with the ways of improving quality time for instruction and implementation of school's philosophy, mission-vision." ranked first, which got the total average of 82 and a weighted average of 4.10 and with a verbal description of almost always. Ranked last is the item "I ask my colleagues on how should the philosophy, mission-vision integrate in my lesson" which received a total weight of 75 and a weighted average of 3.75 with a verbal description of almost always

It shows that most schools are conducting regular meetings (e.g. PLC, Departmental Meeting, Faculty Meeting) to deal with the ways of improving quality time for instruction and implementation of school's philosophy, mission-vision as it reflected in the response of the respondents. This is done to find alternative ways on how to lessen the teachers' burden without sacrificing the schools' philosophy, mission, and vision. This is also one way of maintaining the open communication between the administration and faculty. Respondents considered asking colleagues on how should the philosophy, mission-vision integrate on the learning plan as least favored action. Most respondents are being considerate as to not bothered or disturb their colleagues unless totally helpless or clueless on how to incorporate these statements on the learning plans. 
Table 12

Frequency of the Actions/ Measures to Address the Problems or Concerns

$\begin{array}{cccc}\text { TOTAL } & \text { WEIGHTED } & \text { VERBAL } & \text { RANK } \\ \text { WEIGHT } & \text { AVERAGE } & \text { DESCRIPTION } & \end{array}$

6.1. I manage my time well so 80

4.00

Almost Always

2

that all of the philosophical

ideals should be integrated.

6.2. I ask my colleagues on

how should the philosophy,

mission-vision integrate in

my lesson.

6.3. We have an oversight team to monitor the implementation of school's philosophy, mission and vision.

6.4. Our school is conducting regular meetings (e.g. PLC, Departmental Meeting, Faculty Meeting) to deal with the ways of improving quality time for instruction and implementation of school's philosophy, mission-vision.

\section{Grand Average}

Almost

Always

82

4.10

Almost Always

1

\section{Conclusions}

Based on the findings presented, the following conclusions were drawn.

1. The respondents almost always applied and integrated the schools' ideals as it is reflected to the philosophy, mission-vision statements to their learning plans. Thus, it makes sense that their learning plans are congruent to the schools' aim in achieving quality excellence among the students.

1.1. The respondents almost always aligned their school's philosophy, mission-vision to their learning objectives however there are some respondents who make necessary changes or outright decisions based on the needs or interests of the learners. It means that it is always not necessary that the learning objectives conform to what the philosophy, mission, and vision stated. Therefore, the learning objectives must be flexible in order to attend to children's needs and eventually will lead to the realization of the schools' philosophy, mission and vision.

1.2. The respondents almost always applied or integrated their school's philosophy, mission-vision to their lesson proper or activities. There are respondents who give tasks and activities based on the needs of the learners and there some who make sure that the activities are mandated to the school's 
statements. It implies that teachers' planned activities should be versatile enough to allow adjustments and opportunities for the students to explore and reach their maximum potential, which will manifest the actualization of school's statements.

1.3. The respondents almost always applied or integrated their school's philosophy, mission-vision to the evaluation part of their learning plans. The respondents evaluated the students according to their performance and ability. This goes to show that the teacher is still the one who assesses the students' actions and behavior inside the classroom for they are the overseer and facilitator of what is actually happening inside.

2. The respondents' views are greatly affected by the school's philosophy, mission, and vision. This is to ensure that the materials and resources are anchored on the school's belief, while also accounting for the necessary resources or materials.

3. The respondents are primarily concern with some of the topics that are irrelevant to the schools' philosophy, mission and vision statements since some of the contents are factual based and entails thorough discussion. However, integration of the statements often results to insufficient time to cover necessary topics or lessons.

4. To answer the problems, the schools are conducting regular meetings (e.g. PLC, Departmental Meeting, Faculty Meeting) to deal with the ways of improving quality time for instruction and implementation of school's philosophy, mission-vision and to avoid further escalation of the problems.

\section{Recommendations}

Based on the results of the findings and conclusions gathered, the researchers would like to recommend the following:

1. More emphasis should be given to the integration of the schools' philosophy, mission, and vision to the learning plans, as this will help lead the administrators, teachers, and students toward the achievement of its goals for quality management assurance or accreditation.

2. Based on Table 10, the availability of resources or materials is critical in determining teachers' choice of activity. As a result, the school administrators will make resources available and accessible to enable the teacher to design effective learning objectives that fit with the school's mission, philosophy, and vision.

3. To help schools closely monitor their philosophy, mission, and vision, a watch team should be established that establishes and follows the application and execution of each learning plan and holds regular meetings to focus on their implementation and evaluation of each learning plan.

\section{References:}

[1] Abasolo, Pacita. Personal Management. Manila: GIC Enteprises and Co. Inc. 1991

[2] Bilbao, Purita Brenda C. Gloria S. Avelina L. The Teaching Profession. Quezon City: Lorima Publishing Co. Inc. 2006

[3] Brubacher, John S. Modern Philosophies of Education. New York, McGraw Hill Book Company Inc. 19

[4] Conklin, Kenneth. Theory of Education. Educational Theory. Vol. 24: Issue 1. 2007

[5] D’Souza, Mario O. Interchange- Philosophy, Philosophy of Education, and the Educationof Teachers. Volume 23, Issue 3, 1992

[6] Gitomer, Drew H. Measurements Issues and Assessment for Teaching Quality. California: Corwin Press: A SAGE Company. 2009

[7] Pui-wah, Doris Cheng. Teacher Development- Meta-Learning Ability- A Curricular Development of Teachers in a Changing Context. Vol 12 Number 1. 2008

[8] Ramsey, Robert D. Lifelong Leadership. California: California: Corwin Press: A SAGE Company. 2010

[9] http://www.preservearticles.com/2012030625277/relationship-between-education-and-philosophy-in-themodern-world.html

[10] http://www.ascd.org/publications/books/107042/chapters/Developing-a-Vision-and-a-Mission.aspx 